\title{
Mi escape
}

\section{Natalie Salmerón}

Sabía que yo podía soñar lo que quisiera. Podía manipular mis sueños simplemente con dibujos. Pero al principio no fue tan fácil hacerlo. Tuve que aprender a dibujar. Mi vida era una pesadilla. Por un insomnio insoportable, dormía solamente tres horas cada noche.

Un día, en mis vigilias regulares, le escribí una carta a un amigo en África. Como solía hacerlo, le hice un dibujo al final de la carta. Pero como me quedé dormida, a la jirafa le faltaba una pierna trasera. Nunca me había quedado dormida mientras intentaba completar una carta. Pero el completar mis quehaceres se volvía más y más difícil conforme mi insomnio empeoraba. Esa noche, soñé que montaba una jirafa que era perseguida de predadores. La jirafa no tenía equilibrio y era evidente que caería en las garras de los predadores. Resulta que a la jirafa le faltaba una pierna trasera. Cuando desperté, me aseguré de dibujársela.

Todo mi sueño había ocurrido en el curso de una hora. ¡No había dormido casi nada! Sabía que tendría que dibujar más si quería dormir. Otro día, hacía la tarea de matemáticas y estaba determinada a terminar para dibujar algo espectacular. Me quedé dormida mientras hacía geometría. Vi edificios circulares, triangulares y de todo tipo. Pero había un gran problema. Los edificios no eran tridimensionales, por lo cual todos los objetos que se encontraban en los edificios, muebles, camas, escritorios etc., estaban a plena vista. Mi cama estaba al aire libre y era un día extremadamente frío. ¡Ni en mi sueño pude dormir! Esto era el colmo. Estaba determinada a recorrer mi memoria y ver cuándo comenzó mi insomnio. Vi un video de mi niñez. Entonces supe que la última vez que tuve insomnio fue a la edad de siete años. La única opción que tenía era dibujarme a esa edad. Seguramente podría dormir. Esta vez tuve éxito, no me dormí sin antes terminar el dibujo. Me acosté a dormir, lista para tener un descanso grato. Como niña jugué y jugué, corrí y corrí. Tuve un cansancio enorme y, cuando llegó la noche en el sueño, no dormí. ¿Pero qué había sucedido? Al despertar vi que mi dibujo no se parecía a una niña de siete años, sino mayor. Mis dibujos no eran profesionales. La verdad era que no sabía dibujar. Si iba a usar este don, tendría que aprender a dibujar. No había otra manera de descansar.

Sentí desilusión al saber que había superado la costumbre de dibujar antes de dormir, pero que no había superado mi habilidad para dibujar. Mi última opción era hablar con un dibujante profesional. Mi vecino había dibujado para los juzgados. No le pedí que me enseñara a dibujar porque tomaría demasiado tiempo. En cambio le pedí que dibujara a la niña de siete años. Me dijo que lo haría pero que estaba retirado y que 
le tomaría una semana y estuve de acuerdo. Pero ya no podía más con el cansancio y no pude esperar. Mientras tanto, tenía que hacer algo.

Estaba cansada de estar cansada. Por fin se me ocurrió dibujar mi solución. Para acabar con mi insomnio, dibujé mi cama y en ella escribí aquí duerme Dolores. El problema es que no he despertado. No sé qué sucederá en mi sueño. ¿Quién tendrá el control de mi destino? 